\title{
Promoting Sense of Belonging and Interest in Geosciences among Undergraduate Women through Mentoring
}

Wenyi Du

West Virginia University, wedu@mix.wvu.edu

Follow this and additional works at: https://researchrepository.wvu.edu/etd

Part of the Educational Psychology Commons

\section{Recommended Citation}

Du, Wenyi, "Promoting Sense of Belonging and Interest in Geosciences among Undergraduate Women through Mentoring" (2019). Graduate Theses, Dissertations, and Problem Reports. 4054.

https://researchrepository.wvu.edu/etd/4054

This Thesis is protected by copyright and/or related rights. It has been brought to you by the The Research Repository @ WVU with permission from the rights-holder(s). You are free to use this Thesis in any way that is permitted by the copyright and related rights legislation that applies to your use. For other uses you must obtain permission from the rights-holder(s) directly, unless additional rights are indicated by a Creative Commons license in the record and/ or on the work itself. This Thesis has been accepted for inclusion in WVU Graduate Theses, Dissertations, and Problem Reports collection by an authorized administrator of The Research Repository @ WVU. For more information, please contact researchrepository@mail.wvu.edu. 
Promoting Sense of Belonging and Interest in Geosciences among Undergraduate Women through Mentoring

Wenyi Du

Thesis submitted

to the College of Education and Human Services

at West Virginia University

in partial fulfillment of the requirements for the degree of

Master of Art in

Program Evaluation \& Research

Paul R. Hernandez, Ph.D., Chair

Karen Rambo-Hernandez, Ph.D.

Natalie Shook, Ph.D.

Department of Learning Sciences and Human Development

Morgantown, West Virginia

2019

Key words: sense of belonging, mentor, interest development, college female Copyright 2019 Wenyi Du 


\begin{abstract}
Promoting Sense of Belonging and Interest in Geosciences among Undergraduate Women through Mentoring
\end{abstract}

\begin{abstract}
Wenyi Du
The purpose of this study is to investigate whether students' university sense of belonging mediates the relationship between mentor network diversity and students' interest development among undergraduate women in STEM majors. The sample for this study was consisted of 277 undergraduate women majoring in a STEM discipline with initial interests in geosciences across nine universities within the United States. A regression-based mediation analysis was performed using the Hayes' (2013) macro to test the indirect effect of mentor support on interest through university sense of belonging. Consistent with our hypothesis, the analysis revealed a statistically significant and positive indirect effect of the mentor network diversity on interest in geoscience through university sense of belonging, $a \times b=.04,95 \% \mathrm{CI}=$ [.01,.08]. More specifically, the mentors network diversity positively predicts university sense of belonging $(\mathrm{B}=0.19, \mathrm{p}<.05)$, and in turn university sense of belonging positively predicts students' interest in geoscience $(B=0.20, \mathrm{p}<.05)$. These results imply that undergraduate women's interests can be aroused and maintained through their increased sense of belonging, which can be satisfied by diversifying their mentor network resources.
\end{abstract}




\section{Table of Contents}

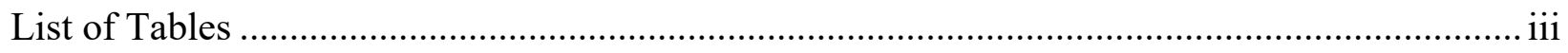

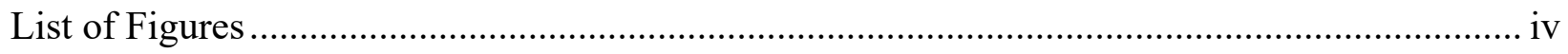

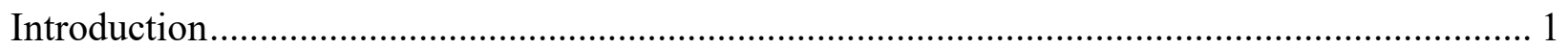

Barriers to women's interest development in STEM ......................................................... 2

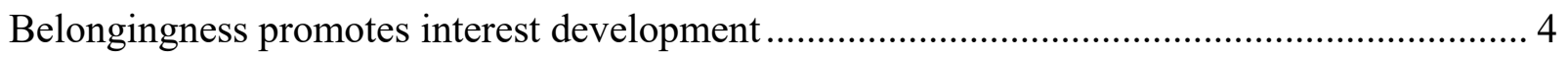

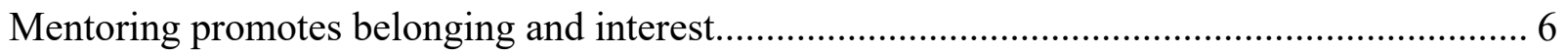

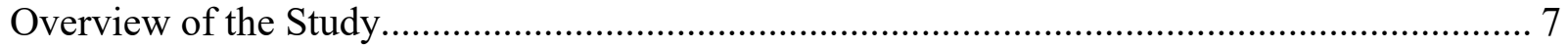

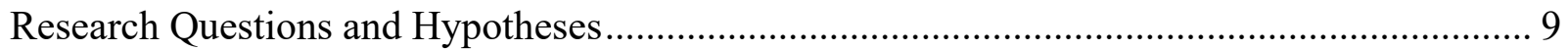

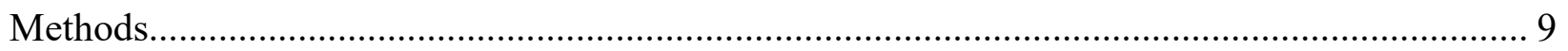

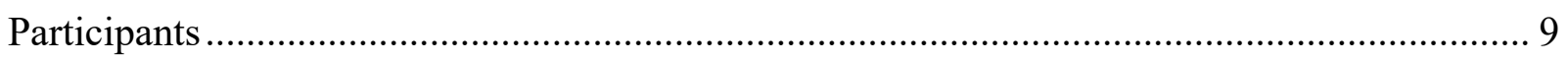

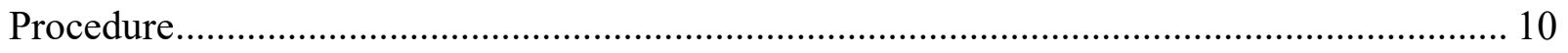

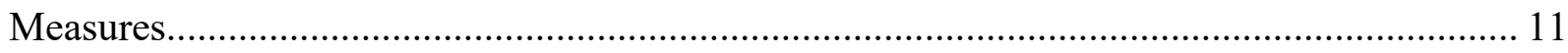

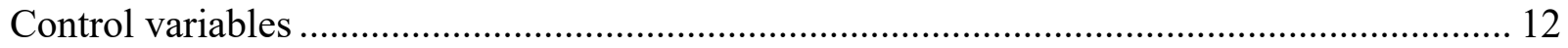

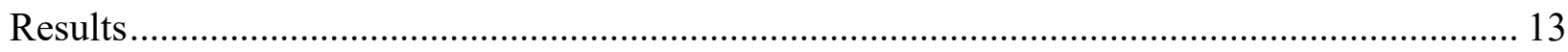

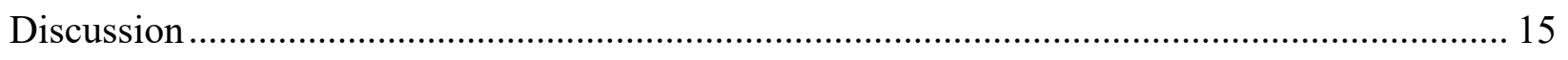

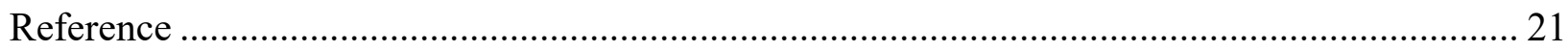

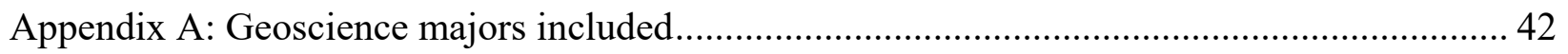

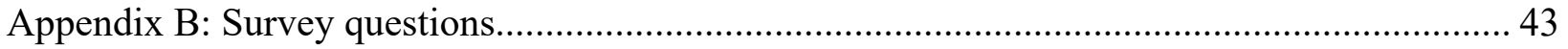

\section{List of Tables}

Table 1. Participants' demographic information. ............................................................. 37

Table 2. Summary of intercorrelations for all the variables. ............................................... 38

Table 3. Summary of Hierarchical Regression with Mentor Diversity Predicting University Sense of Belonging and interest at W6 $(\mathrm{N}=277)$.................................................................... 39

Table 4. Summary of Hierarchical Regression with Gender-matched Faculty Mentor Predicting

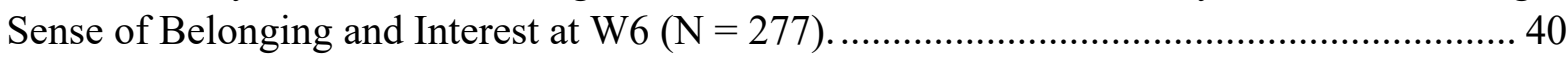




\section{List of Figures}

Figure 1. Theory model of support influence interest development. ....................................... 36

Figure 2. Mediation Analysis. The Effect of Mentor Diversity on Interest in the Geosciences

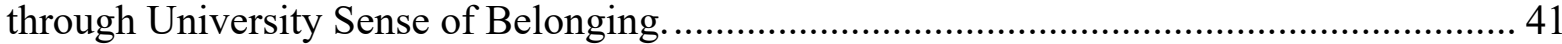




\section{Promoting Sense of Belonging and Interest in Geosciences among Undergraduate Women through Mentoring}

\section{Introduction}

Environmental issues such as increase sea-level, polluted air, and polluted marine environment, have attracted national and international attention. These urgent issues require having qualified people in geoscience fields to minimize or solve environmental problems. As classified by the National Science Foundation (2008), geosciences included a large variety of disciplines, such as Geography, Marine Sciences, Solid and Water Sciences and 19 other majors (See Appendix A).

Women have been historically underrepresented in science, technology, engineering, and mathematic (STEM) disciplines (NSF, 2017). Women are entering higher education institutions at higher rates due to numerous recruitment efforts (NSF, 2017). In disciplines, such as Behavioral Sciences and Biology, the percentage of undergraduate women is equivalent or greater than that of men. However, woman do not enter, and women leave at higher rates in some STEM fields, such as the geosciences (NSF, 2017; Bernard \& Cooperdock, 2018). The percentage of undergraduate women in the Earth and Environmental sciences has increased over time, peaking in 2004 at 49\% (American Geoscience Institution, 2016; Chen, 2013). But by 2017, the percentage of woman in geosciences majors dropped to $38.6 \%$ (NSF, 2017; Bernard \& Cooperdock, 2018).

Woman potentially interested in geoscience-related careers can face numerous barriers, such as negative gender stereotypes or perceived incongruity of social values that can threaten their interest to enter or stay in geoscience majors (Chen, 2013). Mentoring has been identified 
as an important element of comprehensive interventions to reduce the barriers for females' persistence in STEM fields (Syed, Azmitia, \& Cooper, 2011; Estrada, Woodcock, Hernandez, \& Schultz, 2011). In addition, research indicated a positive relationship between interest and selfefficacy, values, and academic performance (Knogler, Harackiewicz, Gegenfurtner, \& Lewalter, 2015).

However, less is known about the degree to which mentoring impacts college students' interest development. The purpose of this study is to examine the direct and indirect effects of mentoring on the development of interests in the geosciences among college women in majoring in STEM. One of the most well-known interest development models was proposed by Hidi and Renninger (2006). It classified interest as four different levels: triggered situational interest, maintained situational interest, emerging individual interest, and well-developed individual interest (see Figure 1). According to Bergin's (2016) interest development model, a key factor influencing interest development is individual's social experiences, particularly individual's social supports. Social support can come from parents, friends, schools, and culture. Bergin's theory emphasizes how social supports can lead to exposure, attention to a topic, which triggers a person's situational interest (see Figure 1). As stated by self-determination theory, relatedness/ belongingness, competence, and autonomy are the three basic needs that motivate humans (Deci \& Ryan, 2000). When the needs are met, interests are then supported. In this study, we focus on the needs to belong (see Figure 1).

\section{Barriers to women's interest development in STEM}

Interest is a product of the interaction between a person's internal motivation and a certain external context (Hidi \& Renninger, 2006; Bergin, 1999; Renninger \& Barach, 2015). The levels of interest are developed from one stage to the next sequentially with continued 
exposure, consistent attention, emotional supports, and increasing stored knowledge (Hidi \& Renninger, 2006; Rotgans \& Schmidt, 2017; Bergin, 2016). The sequence of interest development is not necessarily shown as linear growth. But in most cases, it is an iterative convergence of multiple variables such as experiences, exposures, affordances, and performances (Bergin, 2016). Individual interest was defined as "a psychological state of engaging or the predisposition to reengage with classes of objects, events, or ideas over time." (Hidi \& Renniger, 2006). The desire to engage and reengage with a certain topic has been identified as one of several internal motivation factors driving students to enter and to stay in their majors (Cheryan, Ziegler, Montoya, \& Jiang, 2017; Good, Rattan, \& Dweck, 2012; Hidi \& Renninger, 2006; Thoman, Arizaga, Smith, Story, \& Soncuya, 2015). However, when interest is threated, students can opt out of their desired career path.

For example, although approximately one third of the first-year students express initial interest in STEM majors, but their initial interests in STEM frequently do not last to their graduation. According to NCES report, about $56 \%$ of college students declared a STEM major, and abandoned the chosen STEM major in the next six years (Chen, 2013). Research found that the college dropouts occur most often in students' early-year of college (Bergin, 2016; Browning, McDermott, Scaffa, Booth, \& Carr, 2018). It is important to maintain students' interest throughout their college years, particularly during their early-years of college. Many factors that contribute to the high rates of leaving STEM in early college study have been identified in previous research, including negative gender stereotypes (e.g. people are successful in STEM fields are mostly males) (Fuesting, Diekman, \& Hudiburgh, 2017; Czopp, Kay, \& Cheryan, 2015; Freeman, Anderman \& Jensen, 2007), field-specific ability beliefs (e.g. male are more innate talented on math and science) (Bian, Leslie, Mruphy \& Cimpian, 2017; Elmore \& 
Luna-Lucero, 2017; Ito \& McPherson, 2018), or a lack of same-gender career role model (Hernandez et. al., 2018; Packard, 2003; Cheryan, Drury, \& Vichayapai, 2012). For example, research indicates that women who reported experiencing gender stereotype or brilliance stereotypes expressed less sense of belonging, and less interest in STEM fields (Bian et al, 2017).

A growing body of research is focused on interventions to support women's interest in STEM fields. Empirical studies have designed interventions to increase students' interest in STEM majors by reducing stereotypes. For example, research indicates that changing the classroom environment to be less masculine can minimize gendered stereotypes of STEM majors. Perceiving a greater sense of belonging to the field can significantly increase female students' interest, persistence, and intention to pursue a career in the STEM fields (Cheryan et.al, 2010; Ito \& McPherson, 2018; Lewis et. al, 2017). In addition, previous research had shown that fading the message of "fixed brilliance" or "men are more intelligent than women" helps to promote female's interest in the male-dominated fields (Bian, Leslie, Murphy, \& Gimpian, 2017; Thomam, Arizaga, Smith, Story \& Snocuya, 2014). Furthermore, role modeling has also been shown to be beneficial to women's interest in STEM fields (Hernandez, et. al., 2018; Cheryan et al., 2010; Cheryan, Drury, \& Vichayapai, 2012).

\section{Belongingness promotes interest development}

Sense of belonging is an important psychosocial factor influencing behavior and wellbeing (Twenge, Baumeister, Tice, \& Stucke, 2001, Good, Rattan \& Dweck, 2012; Baumeister \& Leary, 1995;). The need to belong has been conceptualized as a basic need of human beings (Baumeister \& Leary, 1995; Cheryan, Sianna A. Ziegler, Amanda K. Montoya, \& Lily Jiang, 2017; Walton \& Cohen, 2007). Sense of belonging is built up on the interactive relationships 
with others. In other words, sense of belonging is defined as being accepted, valued, and legitimated within a particular group (Walton \& Cohen, 2011; Keonya \& Booker, 2016).

In an academic setting, the sense of belonging has been classified and studied at different levels of abstraction: class belonging (Goodenow, 1993; Midgley, Middleton, Gheen, \& Kumar, 2002; Lewis et al., 2017), professor's pedagogical caring (Clinchy, 2002; Lewis et al., 2017), university belonging (Goodenow, 1993; Shook \& Clay, 2012; Museus, Yi, \& Saelua, 2016), and social acceptance (Walton \& Cohen, 2011; Zumbrunn; Shook \& Clay, 2012). According to Freeman and colleagues (2007), social acceptance, professor's pedagogical caring, and class belonging significantly and positively predict students' university sense of belonging. Thus, we will focus on students' university belonging (see Figure 1).

Sense of belonging has been positively correlated with many educational outcomes. Existing research indicates that students' sense of belonging is positively correlated to students' academic performance (e.g. GPA) (Shook \& Clay, 2012; Goodenow, 1993; Hoffman, Richmond, Morrow, \& Salomone, 2003), willingness to engage and reengage with the topic (Cheryan, et al., 2009; Museus, Yi, \& Saelua, 2017), and to interest and intention to persist in a field of study (Hausmann, Schofield \& Woods, 2007; Layous, et al., 2017).

However, an experiment conducted by Murphy and colleagues (2007) reported that students from minority groups experience belonging uncertainty and become more sensitive to belongingness than their majority peers. Women, as the minority group in the STEM fields, experience belonging uncertainty and sensitively monitor the quality of the social connections to STEM fields (Walton, 2007; Baumeister \& Leary, 1995; Thoman et al., 2014). When women feel less valued, less welcomed or feel pushed away by the chilly climate in STEM, they are more likely to switch to another field or even drop out from their current fields (Hausmann, 
Schofield \& Woods, 2007; Layous, Davis, Garcia, Purdie-Vaughns, Cook \& Cohen, 2017; Thoman et al., 2014).

\section{Mentoring promotes belonging and interest}

Previous research defined the supportive relationships as mentoring. To avoid the inconsistency to the previous literature, we adopted the definition of mentoring as a progressive relationship between a person with more experience (i.e. a faculty member, a graduate student) and a person with less experience (i.e., an undergraduate student). The aim of the relationship is to support the mentee's professional development in the field (Crisp \& Cruz, 2009; Jacobi, 1991; Hernandez, et al., 2017).

How does mentoring affect sense of belonging and interest development? One mechanism identified by Bergin (1999) concerns vivacious interest. Vivacious interest refers interest adaptation from social interactions with others to gain and to maintain social support (See Figure 1). According to social cognitive theories of adolescent development, at any level of schooling, students would be benefit from a supportive interaction with nonparental adults (Freeman et al., 2007; London, Rosenthal, Levy, \& Lobel, 2011; Murpy et al., 2007; Museus et al., 2016).

Existing research indicates mentoring has positive impacts on students' perceived compatibility (Rosenthal, Levy \& London, 2013), sense of belonging (Museus et al., 2016), interest (Shin, Levy \& London, 2016; Good, Rattan \& Dweck, 2012), and intention to persist (Rotgans \& Schmidt, 2017; Cheryan et al., 2011; Cheryan et al., 2006), particularly when the mentees regard the mentors as their role models (Hernandez, et al., 2017). Research indicated that early-undergraduate students may have limited experience working with a faculty mentor. Instead, most of them had post-graduate level mentors, such as a master or a doctoral student 
mentor (Shin, Levy \& London, 2016; Aikens, Robertson, Sadselia, Watkins, Evans, Runyon, Eby, \& Dolan, 2017; Twenge, Baumeister, Tice, \& Stucke, 2001).

Mentoring scholars have proposed that "individuals may not rely upon only one but multiple mentoring resources to support their professional career development" (Baugh \& Scandura, 1999; Thomas \& Higgins). Mentor network diversity indicates how many types of mentors a mentee has access to. The mentee benefits from greater mentor network diversity through less redundant information (Higgins \& Kram, 2001). Hence, in this study, the mentor network diversity was defined as the total number of different mentor sources, such as, one's academic advisor, master and doctor student mentors, tie to the mentee's network within the university.

In addition to the types of mentor, research indicates that the gender of the mentor may influence the quality of mentorship. Mentoring theories illuminate that female undergraduate students may benefit from having same-gender mentors more compared to having differentgender mentors in the STEM fields (Lockwood, 2006; Blake-Beard, Bayne, Crosby \& Muller, 2011). Empirical studies indicated that having a same-gendered mentor may increase women's perceived compatibility, perceived similarity, sense of belonging, and coauthoring experience in STEM fields (Cheryan et al., 2006; Rosenthal, Levy \& London, 2013; Hernandez, et al., 2017).

\section{Overview of the Study}

The current study focuses on the effects of different aspects of mentoring on university sense of belonging and interest development. Undergraduate students may have more than one type of mentor and may benefit from the mentor network diversity. Based on the mentoring theory and empirical studies, faculty mentors may promote at least three outcomes: coauthoring experiences, perceived identity similarity, and sense of belonging. Peer and other source of 
mentoring may provide support to students' sense of belonging towards the institution or towards the fields (Hoffman et al., 2003; Johnson, 2013; Museus et al., 2016; Kivlighan et al., 2018).

The purpose of this study is to examine the direct and indirect effects of mentoring relationships on the interest development in geosciences among college women in STEM. This study will fill the gap of how the university sense of belonging is impacted by mentor network diversity and having a gender-matched faculty mentor, and how belonging may in turn affect women's interest in geosciences. Data for this study were drawn from a larger study of female STEM students' academic journeys, entitled the “Analysis of Women's Advancement, Retention, and Education in Science (AWARES)". The AWARES study longitudinally follows a sample of college women recruited from nine universities in two regions of the United States: Colorado, Wyoming (the Front Range), and North and South Carolina (the Carolinas) since Fall 2015. First or second-year of undergraduate women in STEM majors (or those intending to pursue STEM major) were recruited to participate in the AWARES study. Approximately half of the AWARES study participants participated in a professional development and mentoring program (i.e., PROGRESS program). Online surveys were distributed every semester since Fall 2015 to collect data.

Previous research has shown positive effects of mentoring support on undergraduate students' general social sense of belonging (i.e. peer belonging) (Goodnow, 1993; Freeman, Anderman, \& Jensen, 2007; Thoman, Arizaga, Smith, Story, \& Soncuya, 2015; Ribera, Miller, \& Dumford, 2017). However, less is known about the effect of a student's mentor network diversity on their sense of belonging to their university. Furthermore, Hernandez and his colleagues (2016) found that undergraduate students with same-gender faculty had reported more co-authoring experiences than with same gender mentors. However, there is limited research 
showing that female undergraduate students' sense of belonging would be affected by the gender of their faculty mentors. In addition, previous research has shown the science identity (Herenandez et al., 2017), perceived similarity (Cheryan \& Plaut, 2010), and utility value (Hulleman \& Harackiewicz, 2009; Harackiewicz, Canning, Tibbetts, Priniski, \& Hyde, 2016) can mediate the relationship between mentoring and students' interest. Moreover, there is less research on the role of university sense of belonging as a mediator in the relationship between mentor network diversity and interest. To fill these gaps, this study aimed to answer the following research and hypotheses.

\section{Research Questions and Hypotheses}

Does sense of belonging mediate the relationship between mentor network diversity or having a gender-match faculty mentor and interest in geosciences? Three hypotheses were proposed as the following:

1. Mentor network diversity and having a gender-matched faculty mentor would positively predict women's university sense of belonging;

2. University sense of belonging would positively predict women's interest in geosciences;

3. Mentor network diversity and having a gender-matched faculty mentor would positively predict women's interest in geosciences.

\section{Methods}

\section{Participants}

The overall sample of the AWARES study consisted of 484 female undergraduate students. In Fall 2018, 386 participants took the survey, while 98 did not take the survey. A Pearson's chi-square test was conducted based on the recruiting survey to test the differences 
between the participants who took the survey in Fall 2018 and these who did not. The result revealed there was no significant differences between the two groups based on year in school $\left(\chi^{2}\right.$ $=.87, d f=3, p=.83)$, recruitment cohort $\left(\chi^{2}=.87, d f=3, p=.83\right)$, race $\left(\chi^{2}=1.72, d f=1, p\right.$ $=.19)$, or their interest participating in a longitudinal research study $\left(F_{(1,482)}=.09, p=.77\right)$.

However, the PROGRESS member students showed higher completion rate than these who were not in the mentoring program $\left(\chi^{2}=13.12, d f=1, p<.01\right)$.

Among 386 participants took the survey (see Table 1), 86 participants were removed because they were no longer undergraduate students, and 23 participants were removed during the regression analysis using list-wise deletion due to missing at least one of the variables. A total of 277 participants were included in the data analysis.

\section{Procedure}

The participants were initially recruited via email (i.e., email addresses obtained from university registrar office), in-person recruiting announcement in the introductory STEM courses (e.g., Physics 101), and recruitment flyer posted across the campuses. Students interested in participating in the study completed a screening survey and received gifts for their efforts ( $\$ 5$ Starbucks card). Only students who met the following criteria were invited to participate in the study: first- or second- year of college, identify as female, intention to have a STEM major, and interested in geosciences. Participants were recruited from nine universities in the Colorado/Wyoming Front Range and the Carolinas. The participants were recruited as two cohorts: Fall 2015 and Fall 2016. About 50\% of the participants attended to the mentoring weekend workshops (e.g. PROGRESS). Participants were invited to complete longitudinal follow-up surveys thereafter (Fall \& Spring) till Spring 2019. Data collection has been performed using Qualtrics, an online survey system. Participants received either $\$ 10$ e-Gift card or $\$ 10$ 
direct deposit to their PayPal account for their participation. All procedures were approved by the local IRB. The data used in this study was collected in Spring and Fall 2018.

\section{Measures}

Mentor network diversity. Participants were given the following definition of mentoring: "A mentor is someone who provides guidance, assistance, and encouragement on professional and academic issues. A mentor is more than an academic advisor and is someone you turn to for guidance and assistance beyond selecting classes or meeting academic requirements." With that definition in mind, participants were asked: "1) if there is faculty member, 2) a graduate student, 3) a peer, or 4) other university faculty member that they would consider as a mentor?". The participants' responses to each category mentor were dummy coded into 1 (Yes) and 0 (No). This variable presented the sum of all types of mentors. This variable ranged from zero to four. The mentor network diversity variable data was collected during Spring 2018.

Gender-matched faculty mentor. If the participants report having a faculty mentor, follow-up question asked the gender of their faculty mentor. This variable was dummy coded into 0 (not gender-matched) and 1 (gender-matched). Both "Woman/Female" and "Transgender woman" gender identities were coded as " 1 ".

University sense of belonging. University sense of belonging was measured with eightitems adapted from Shook and Clay (2012). Participants reported their perceived sense of belonging to their university (e.g. "I am enthusiastic about attending my university.") on a sevenpoint Likert scale from strongly disagree (1) to strongly agree (7). The scale scores were derived by taking the average of the eight items, with a higher score indicating the higher level of university sense of belonging. University sense of belonging scores have exhibited high internal 
consistency reliability in the previous research (Cronbach's $\alpha=.92$ ) (Shook \& Clay, 2012). Data of university sense of belonging was collected in the survey of Fall 2018.

Interest in the geosciences. Students' interest in geosciences was measured with a twoitem measure adapted from the prior literature of interest development (Hulleman \& Harackiewicz, 2009). Participants rated their level of interests to each of the following: 1) "How interested are you in taking courses in Earth Systems or Environmental Sciences?" and 2) "How interested are you in pursuing an Earth Systems or Environmental Sciences Career?” on a sevenpoint Likert scale from not at all interested (1) to very interested (7). Scales scores were derived by taking the average of the two items, with a higher score indicating a higher level of interest in the geosciences. The interest scales had exhibited a high internal consistency reliability in previous research (Cronbach's $\alpha=.86$ ) (Hernandez et al., 2017). The interest in the geosciences measure was collected on both the initial recruitment survey (i.e., Fall 2015 or 2016) and in the Fall 2018 survey.

\section{Control variables}

PROGRESS membership. The participants in this study did or did not participant in the PROGRESS program. Their membership was dummy coded as PROGRESS member (1) or nonPROGRESS membership (0).

University. Students from nine universities participated in this study: Colorado College, Colorado State University, Metro State University Denver, North Carolina A\&T, North Carolina State University, University Colorado - Boulder, University of North Carolina - Charlotte, University of South Carolina, and University of Wyoming. The university variable was dummycoded with Colorado State University as the reference group. 
Cohort statues. The cohort statues refer which year the student had been recruited. Cohort has been dummy-coded as 1 (Fall 2015, cohort 1) and 0 (Fall 2016, cohort 2) as a control variable.

\section{Statistical assumptions and preliminary analyses}

Prior to running regression and mediation analyses, the data were examined for outliers, missing data severity, and regression assumptions in SPSS software version 25. There was no evidence indicating extreme outliers (e.g., leverage, Cook's D values were acceptably small; Judd, McClelland, \& Ryan, 2009). The pattern of missing data were consistent with the restrictive assumption of missing completely at random (e.g., Little's MCAR test was not significant, $\chi^{2}=10.96, \mathrm{df}=11, \mathrm{p}=.45$ ). And the assumptions of regression were met (e.g., Q-Q plots showed normality for most of the variables). Finally, we tested the independence assumption was due to the students being nested within universities. The clustering effects were examined using HLM software student version 7.03. The ICC presented the proportion of variance between universities to the total variance. The ICC revealed the variances of interests in geosciences located mainly among individuals $\left(\mathrm{ICC}_{\text {interest }}=.01\right)$ and the variance of university sense of belonging was also mainly explained at the individual level $\left(\mathrm{ICC}_{\text {belongingness }}=.07\right)$. The ICC for sense of belonging was non-ignorable. Thus, we included universities as covariates in mediation analysis.

\section{Results}

\section{Intercorrelations}

The goal of this study was to examine university sense of belonging as a mediator between mentoring and interest in geosciences. Specifically, we examined mentoring from two 
aspects: 1) mentor network diversity and 2) having a gender-matched faculty mentor. Prior to conducting formal mediation hypothesis tests, the pattern of associations were examined.

An intercorrelation analysis revealed that students' university sense of belonging was positively and significantly correlated with students' initial interest in geosciences, having a faculty mentor, and mentor network diversity. And students' interest in geosciences was significantly and positively correlated with cohort, having a faculty mentor, having a gendermatched faculty mentor, mentor network diversity, students' university sense of belonging, and moderately correlated with students' initial interest in geosciences. With a small portion of participants reported having a gender-matched faculty mentor, a significantly positive correlation between having a gender-matched faculty mentor and interest in geosciences was found (see Table 2).

\section{Mediation analyses}

Two hierarchical regression analyses were conducted to predict interest separately with two predictors: 1) mentor network diversity and 2) gender-matched faculty mentor. The variance of students' university sense of belonging was significantly explained by mentor network diversity, but not by having a faculty mentor. The variance of students' interest in geosciences was significantly explained by university sense of belonging, mentor network diversity, but not by having a gender-matched faculty mentor. (see Table $3 \&$ Table 4 ).

With these results above, mediation analyses were performed to formally address the research question and hypotheses. The Hayes' (2013) macro was used to test the mediation effect of university sense of belonging on the relationship between mentor network diversity and interest in the geosciences, controlling for university, PROGRESS membership, cohort and initial interest in the geosciences. The mediation analysis was performed (PROCESS Model 4) 
with 20,000 bootstrapped samples to construct $95 \%$ confidence intervals (CIs) around the indirect effect. Consistent with our hypothesis, students with more mentor network diversity reported higher university sense of belonging $(B=.19, S E=.05,95 \% C I=[.09, .31])$. Students with higher university sense of belonging expressed higher interest in geosciences $(B=.20, S E$ $=.10,95 \% C I=[.0004, .40])$. The analysis revealed a statistically significant and positive indirect effect of mentor network diversity on interest in the geoscience through university sense of belonging, $a \times b=.04,95 \% C I=[.01, .08]$. The partially standardized effect size $(\beta=.04)$ indicated that student having one more mentor expressed .04-standard deviation higher interest in geosciences, as a result of the effect of mentor network diversity on university sense of belonging (see Figure 2).

The mediation test for having a gender-matched faculty mentor was unnecessary, on interest in the geosciences through university sense of belonging. The results indicated that students having a gender-matched faculty mentor reported was not predictive of with university sense of belonging, although sense of belonging was still predictive of interest in the geosciences, Table 4 . The analysis revealed a positive but not statistically significant indirect effect of the gender-matched faculty mentor on interest in the geoscience through university sense of belonging, $a \times b=.03,95 \% \mathrm{CI}=[-.12, .33]$.

\section{Discussion}

This study was designed to investigate if mentor network diversity and gender-matched faculty mentor impact female undergraduate students' university sense of belonging, which in turn may affect their interest in geosciences. First, consistent with our hypothesis, university sense of belonging positively mediated the relationship between mentor network diversity and interest in geosciences. Precisely, higher mentor network diversity predicted higher university 
sense of belonging, consecutively, higher university sense of belonging predicted higher interest in geosciences. Second, though the university sense of belonging did not mediate the relationship between having a gender-matched faculty mentor as our hypothesized, the correlation analysis reveals that students' interest in geoscience is positively correlated with having a gendermatched faculty mentor.

\section{Significance of The Study}

These findings are consistent with previous studies in that a) interest was predicted by students' sense of belonging (Thoman et al., 2014; Goodenow,1993) and b) mentoring positively impacted students' interest (Hernandez et al., 2017). But this study extends STEM mentoring and interest development literature in two important ways. First, instead of using one mentoring source as the primary predictor, this study used mentor network diversity to examine the total effect of mentoring. It provided a conceptual lens to boost students interest development by varying the ways accessing different types of mentoring. Second, university sense of belonging was empirically examined as the mediator of mentor network diversity and interest development, which has not been done by previous research.

\section{Limitations}

Though this study extended women's interest development and mentoring literature in STEM in different ways, there are several limitations need to be noted. First, the limitation of the sample. The prime limitation was that participants in this study were not randomly sampled, but were rather a sample of first- and second-year female undergraduate STEM majors interested in the geosciences. In addition, a majority of the participants were in the third or the fourth year of the college at the time we collected the data for this study. As documented in previous research, 
students in the third or fourth year of college may have higher sense of belonging to their university than early-year college students (Good, Rattan, \& Dweck, 2012; Freeman et al., 2007). In addition, we did not measure the participants' initial university sense of belonging on the early data collection survey. Further, only a small portion of participants were actually majoring in geosciences, but we used students' interest in geosciences as our predicted outcome. Even only $21.9 \%$ of the sample majored in geosciences, all the participants showed initial interest in geosciences to some degree to be included in this study. Although the mean of interest in geosciences at was 4.01, which was an average score on the scale (see Table 1). A t-test revealed that there was an overall significant increase between participants' initial interest in geosciences and their interest in geosciences in Fall $2018\left(\mathrm{t}_{(1,276)}=8.60, \mathrm{p}<.01\right)$, despite their majors.

Second, the mentor network diversity was measured by the number of total mentors, which did not reflect the different roles of mentors. To better understand the components of participants' mentor network diversity, we examined the number of different types of mentors. We found that the most frequent mentoring resource were peer mentors $(n=144,51.8 \%)$, followed by faculty mentors $(\mathrm{n}=136,48.9 \%)$ and another faculty mentor $(\mathrm{n}=89,32.0 \%)$, while the least frequent mentoring type was graduate students $(n=65,23.4 \%)$ reported in this study. Besides, lack of information of mentors' disciplinary is another limitation in this study. Even we gave the definition of mentoring, we did not limit to or ask for the mentor's disciplinary. Thus, mentors may not be supporting geosciences interest specifically.

\section{Practice Implications}

This study focused on women in geosciences, a subfield of STEM. This model may still be applicable to other STEM majors for the following two reasons: First, it's a common 
phenomenon that women face gender-based barriers to degrees and careers in STEM. In this study, it revealed a positive impact of mentoring on women's sense of belonging. Second, there are many of general required courses across STEM fields. Thus, the basic trainings are similar across early college STEM education. Students have possibility to specify or switch within STEM disciplines. For example, one of our participants entered geosciences master's program with a biology bachelor's degree.

Our findings are of use to educational psychologists and university administrates to promote women's interest development and sense of belonging through mentoring. Instead of having the number of mentors increased, universities may pay more attention on how to diversify the role of mentors. To be more specific, the mentor network diversity may be achieved by the following implications. First, a mentoring workshop may be an efficient way for students to build connections to peer mentors and faculty mentors within the university. Workshops may offer opportunities to identify the barriers women are facing in STEM, to build connections to peers with similar interest, and to be advised with research experience applications. Through the workshops, students may know mentors in-person and may maintain the relationships via social media.

Second, it's also important to encourage graduate students become mentors to undergraduate students. In this study, graduate student mentors were the lease frequent reported mentoring resource $(n=65,23.4 \%)$. However, comparing the ratio of faculty to undergraduate students verses the ration of graduate students to undergraduate students, it should be more accessible to have a graduate mentor than having a faculty mentor. Having graduate students as mentors may encourage undergraduate students to take one step further, such as applying for a master's degree, in related fields. 
Third, university may hold conferences to help students build connections to professionals outside of the university, including professors from other universities, professionals in industries. In conferences, students may get exposures to the most in trend scientific innovations, to an influential professor in the field, and to meet their "career role models". Conferences can be the window sending welcome message to women encouraging them to enter and to stay, and may help students to gain knowledge beyond textbooks, to explore unknows, and to specify their interests.

\section{Conclusion and Future Directions}

Most educational psychology research on promoting STEM diversity focus on the reasons pushed women away from the science fields. However, this study examines the phenomenon from the perspective of psychosocial view, indicating that mentoring and sense of belonging can promote women's interest development, which potentially increase their intention to stay in STEM fields. The results suggested that women benefit from multiple mentoring connections by confirming their sense of belonging. To minimize the issues gender disparities brings to STEM, this study illustrated the importance of building individual connections to promote students' experience across campus and within STEM.

In a nutshell, the results of this study insights several paths for future study. First, future researcher of mentoring would benefit from using multiple data sources, such as individual interview and focus group, to capture the precise relationship between mentor network diversity, sense of belonging and their interest development. In addition, even we know that students benefit from the mentor network diversity, but it would be interesting to investigate which source of the mentoring is most efficient way expanding the connections. Third, future study will be 
needed to further explore sense of belonging towards the STEM fields. Thus, future study will answer whether the sense of belonging predicts females' actual retention in STEM fields. 


\section{Reference}

Baugh, S. G., \& Scandura, T. A. (1999). The effect of multiple mentors on protege attitudes toward the work setting. Journal of Social Behavior \& Personality, 14(4), 503-521.

Baumeister, R. F., \& Leary, M. R. (1995). The need to belong: Desire for interpersonal attachments as a fundamental human motivation. Psychological Bulletin, 117(3), 497.

Bergin, D. A. (2016). Social Influences on Interest. Educational Psychologist, 51(1), 7-22. doi:10.1080/00461520.2015.1133306

Bergin, D. A. (1999). Influences on classroom interest. Educational Psychologist, 34(2), 87-98.

Bernard, R. E., \& Cooperdock, E. H. G. (2018). No progress on diversity in 40 years. Nature Geoscience, 11(5), 292-295. doi:10.1038/s41561-018-0116-6

Bian, L., Leslie, S.-J., Murphy, M. C., \& Cimpian, A. (2018). Messages about brilliance undermine women's interest in educational and professional opportunities. Journal of Experimental Social Psychology, 76, 404-420. doi: 10.1016/j.jesp.2017.11.006

Booker, K. (2016). Connection and Commitment: How Sense of Belonging and Classroom Community Influence Degree Persistence for African American Undergraduate Women. International Journal of Teaching and Learning in Higher Education, 28(3), 218-229.

Booker, K. C., Merriweather, L., \& Campbell-Whatley, G. (2016). The Effects of Diversity Training on Faculty and Students' Classroom Experiences. International Journal for the Scholarship of Teaching and Learning, 10(1). doi:10.20429/ijsotl.2016.100103 
Browning, B. R., McDermott, R. C., Scaffa, M. E., Booth, N. R., \& Carr, N. T. (2018). Character Strengths and First-Year College Students' Academic Persistence Attitudes: An Integrative Model. Counseling Psychologist, 46(5), 608-631. doi:10.1177/0011000018786950

Canning, E. A., Muenks, K., Green, D. J., \& Murphy, M. C. (2019). STEM faculty who believe ability is fixed have larger racial achievement gaps and inspire less student motivation in their classes. Science Advances, 5(2). doi:10.1126/sciadv.aau4734

Chen, X., \& Soldner, M. (2013). STEM attrition: College students' paths into and out of STEM fields. In Report NCES 2014-001 U.S. Department of Education. doi: nces.ed.gov/pubs2014/2014001rev

Cheryan, S., Master, A., \& Meltzoff, A. N. (2015). Cultural stereotypes as gatekeepers: increasing girls' interest in computer science and engineering by diversifying stereotypes. Front Psychol, 6(49). doi: org/10.3389/fpsyg.2015.00049

Cheryan, S., \& Plaut, V. C. (2010). Explaining Underrepresentation: A Theory of Precluded Interest. Sex Roles, 63(7), 475-488. doi: org/10.1007/s11199-010-9835-x

Cheryan, S., Plaut, V. C., Davies, P. G., \& Steele, C. M. (2009). Ambient belonging: how stereotypical cues impact gender participation in computer science. J Pers Soc Psychol, 97(6), 1045-1060. doi: 10.1037/a0016239

Cheryan, S., Drury, B. J., \& Vichayapai, M. (2012). Enduring Influence of Stereotypical Computer Science Role Models on Women's Academic Aspirations. Psychology of Women Quarterly, 37(1), 72-79. doi:10.1177/0361684312459328 
Cheryan, S., Ziegler, S. A., Montoya, A. K., \& Jiang, L. (2017). Why are some STEM fields more gender balanced than others? Psychological Bulletin, 143(1), 1-35. doi: org/10.1037/bul0000052

Cohen, G. L., \& Garcia, J. (2008). Identity, belonging, and achievement: A model, interventions, implications. Current Directions in Psychological Science, 17(6), 365-369. doi: 10.1111/j.1467-8721.2008.00607.x

Crisp, G., \& Cruz, I. (2009). Mentoring college students: A critical review of the literature between 1990 and 2007. Research in Higher Education, 50(6), 525-545. doi: $10.1007 / \mathrm{s} 11162-009-9130-2$

Czopp, A. M., Kay, A. C., \& Cheryan, S. (2015). Positive stereotypes are pervasive and powerful. Perspective Psychological Science, 10(4), 451-463. doi:

$10.1177 / 1745691615588091$

Dasgupta, N. (2011). Ingroup experts and peers as social vaccines who inoculate the selfconcept: The stereotype inoculation model. Psychological Inquiry, 22(4), 231-246. doi: $10.1080 / 1047840 X .2011 .607313$

Eccles, J. S., \& Wigfield, A. (2002). Motivational beliefs, values, and goals. Annual Review of Psychology, 53, 109-132. doi:10.1146.53.100901.135153

Estrada, M., Woodcock, A., Hernandez, P. R., \& Schultz, P. W. (2011). Toward a model of social influence that explains minority student integration into the scientific community. Journal of Educational Psychology, 103(1), 206-222. doi: 10.1037/a0020743 
Faul, F., Erdfelder, E., Buchner, A., \& Lang, A.-G. (2009). Statistical power analyses using G*Power 3.1: Tests for correlation and regression analyses. Behavior Research Methods, 41, 1149-1160.

Fisher, A. J., Mendoza-Denton, R., Patt, C., Young, I., Eppig, A., Garrell, R. L., \& Richards, M. A. (2019). Structure and belonging: Pathways to success for underrepresented minority and women PhD students in STEM fields, PloS One, 14(1). doi: 10.1371/journal.pone.0209279

Freeman, T. M., Anderman, L. H., \& Jensen, J. M. (2007). Sense of belonging in college freshmen at the classroom and campus levels. The Journal of Experimental Education, 75(3), 203-220. doi: 10.3200/JEXE.75.3.203-220

Fryer, L. K. (2015). Predicting self-concept, interest and achievement for first-year students: The seeds of lifelong learning. Learning and Individual Differences, 38, 107-114. doi: 10.1016/j.lindif.2015.01.007

Fuesting, M. A., Diekman, A. B., \& Hudiburgh, L. (2017). From classroom to career: the unique role of communal processes in predicting interest in STEM careers. Social Psychology of Education, 20(4), 875-896. doi: 10.1007/s11218-017-9398-6

Gaspard, H., Dicke, A. L., Flunger, B., Brisson, B. M., Häfner, I., Nagengast, B., \& Trautwein, U. (2015). Fostering adolescents' value beliefs for mathematics with a relevance intervention in the classroom. Developmental Psychology, 51(9), 1226-1240. doi: $10.1037 / \operatorname{dev} 0000028$ 
Gelso, C. J., Kivlighan, D. M., \& Markin, R. D. (2018). The Real Relationship and Its Role in Psychotherapy Outcome: A Meta-Analysis. Psychotherapy, 55(4), 434-444. doi: $10.1037 /$ pst0000183

Good, C., Rattan, A., \& Dweck, C. S. (2012). Why do women opt out? Sense of belonging and women's representation in mathematics. Journal of Personality and Social Psychology, 102(4), 700. doi: 10.1037/a0026659

Goodenow, C. (1993). The psychological sense of school membership among adolescents: Scale development and educational correlates. Psychology in the Schools, 30(1), 79-90.

Harackiewicz, J. M., Durik, A. M., Barron, K. E., Linnenbrink-Garcia, L., \& Tauer, J. M. (2008). The role of achievement goals in the development of interest: Reciprocal relations between achievement goals, interest, and performance. Journal of Educational Psychology, 100(1), 105. doi: $10.1037 / 0022-0663.100 .1 .105$

Harackiewicz, J. M., Canning, E. A., Tibbetts, Y., Giffen, C. J., Blair, S. S., Rouse, D. I., \& Hyde, J. S. (2014). Closing the social class achievement gap for first-generation students in undergraduate biology. Journal of Educational Psychology, 106(2), 375-389. doi: $/ 10.1037 / \mathrm{a} 0034679$

Harackiewicz, J. M., Canning, E. A., Tibbetts, Y., Priniski, S. J., \& Hyde, J. S. (2016). Closing achievement gaps with a utility-value intervention: Disentangling race and social class. Journal of Personality and Social Psychology, 111(5), 745-765. doi: 10.1037/pspp0000075 
Harackiewicz, J. M., Smith, J. L., \& Priniski, S. J. (2016). Interest matters: the importance of promoting interest in education. Policy Insights from the Behavioral and Brain Sciences, 3(2), 220-227. doi: 10.1177/2372732216655542

Hausmann, L. R. M., Schofield, J. W., \& Woods, R. L. (2007). Sense of belonging as a predictor of intentions to persist among African American and white first-year college students. Research in Higher Education, 48(7), 803-839. doi: 10.1007/s11162-007-9052-9

Hayes, A., \& Little, T. (2018). Introduction to mediation, moderation, and conditional process analysis : A regression-based approach (Second ed., Methodology in the social sciences). New York: Guilford Press.

Hernandez, P. R., Bloodhart, B., Barnes, R. T., Adams, A. S., Clinton, S. M., Pollack, I., ... Fischer, E. V. (2017). Promoting professional identity, motivation, and persistence: Benefits of an informal mentoring program for female undergraduate students. Plos One, 12(11). doi: org/10.1371/journal.pone.0187531

Hernandez, P. R., Bloodhart, B., Adams, A. S., Barnes, R. T., Burt, M., Clinton, S. M., ..., Fischer, E. V. (2018). Role modeling is a viable retention strategy for undergraduate women in the geosciences. Geosphere, 14(6), 2585-2593. doi: /10.1130/GES01659.1

Hernandez, P. R., Estrada, M., Woodcock, A., \& Schultz, P. W. (2016). Protégé perceptions of high mentorship quality depend on shared values more than on demographic match. The Journal of Experimental Education, 85(3), 450-468. 
Hidi, S., \& Renninger, K. A. (2006). The four-phase model of interest development. Educational Psychologist, 41(2), 111-127.

Higgins, M. C., \& Kram, K. E. (2001). Reconceptualizing mentoring at work: a developmental network perspective. In Source: The Academy of Management Review, 26(2), 264-288. doi: 10.5465/amr.2001.4378023

Hoffman, M., Richmond, J., Morrow, J., \& Salomone, K. (2003). Investigating "sense of belonging" in first-year college students. Journal of College Student Retention, 4(3), 227256. doi: 10.2190/DRYC-CXQ9-JQ8V-HT4V

Hulleman, C. S., \& Harackiewicz, J. M. (2009). Promoting interest and performance in high school science classes. Science, 326(5958), 1410-1412. doi: 10.1126/science.1177067

Ito, T. A., \& McPherson, E. (2018). Factors influencing high school students' interest in pSTEM. Frontiers in Psychology, 9(1535). doi: 10.3389/fpsyg.2018.01535

Johnson, D. R. (2013). College students' sense of belonging: a key to educational success for all students. Journal of College Student Development, 54(6), 662-663.

Judd, C. M., McClelland, G. H., \& Ryan, C. S. (2017). Data Analysis: a Model Comparison Approach To Regression, ANOVA, and Beyond, Third Edition (3rd ed.). New York, NY: Routledge.

Kember, D., Hong, C., Ho, A., \& Ho, A. (2011). More can mean less motivation: Applying a motivational orientation framework to the expanded entry into higher education in Hong Kong. Studies in Higher Education, 36(2), 209-225. doi: 10.1080/03075070903514062 
Kivlighan, D. M., Abbas, M., Gloria, A. M., Aguinaga, A., Frank, C., \& Frost, N. D. (2018). Are belongingness and hope essential features of academic enhancement groups? A psychosocial cultural perspective. Journal of Counseling Psychology, 65(2), 204-213. doi: $10.1037 /$ cou0000266

Knogler, M., Harackiewicz, J. M., Gegenfurtner, A., \& Lewalter, D. (2015). How situational is situational interest? Investigating the longitudinal structure of situational interest. Contemporary Educational Psychology, 43, 39-50. doi: 10.1016/j.cedpsych.2015.08.004

Layous, K., Davis, E. M., Garcia, J., Purdie-Vaughns, V., Cook, J. E., \& Cohen, G. L. (2017). Feeling left out but affirmed: Protecting against the negative effects of low belonging in college. Journal of Experimental Social Psychology, 69, 227-231. doi: 10.1016/j.jesp.2016.09.008

Lewis, K. L., \& Hodges, S. D. (2015). Expanding the concept of belonging in academic domains: Development and validation of the ability uncertainty scale. Learning and Individual Differences, 37, 197-202. doi: 10.1016/j.lindif.2014.12.002

Lewis, K. L., Stout, J. G., Pollock, S. J., Finkelstein, N. D., \& Ito, T. A. (2016). Fitting in or opting out: A review of key social-psychological factors influencing a sense of belonging for women in physics. Physical Review Physics Education Research, 12(2). doi: 10.1103/PhysRevPhysEducRes.12.020110

Lewis, K. L., Stout, J. G., Finkelstein, N. D., Pollock, S. J., Miyake, A., Cohen, G. L., \& Ito, T. A. (2017). Fitting in to Move Forward: Belonging, Gender, and Persistence in the Physical 
Sciences, Technology, Engineering, and Mathematics (pSTEM). Psychology of Women Quarterly, 41(4), 420-436. doi:10.1177/0361684317720186

London, B., Rosenthal, L., Levy, S. R., \& Lobel, M. (2011). The Influences of Perceived Identity Compatibility and Social Support on Women in Nontraditional Fields During the College Transition. Basic and Applied Social Psychology, 33(4), 304-321. doi:

$10.1080 / 01973533.2011 .614166$

Luna-Lucero, M., \& Elmore, K. (2017). Mistake Detection Videos to Improve Students' Motivation in Math. International Journal of Designs for Learning. doi: org/10.14434/ijdl.v8i2.23073

Lynch, R. (2017). Towards an Understanding of Interest Development: Challenges and Opportunities for Psychologists and Counsellors in Schools. Journal of Psychologists and Counsellors in Schools, 27(2), 208-221. doi: 10.1017/jgc.2016.27

Martinez-Callaghan, J., \& Gil-Lacruz, M. (2017). Developing identity, sense of belonging and social networks among Japanese immigrants in Scotland and Spain. Asian and Pacific Migration Journal, 26(2), 241-261. doi: 10.1177/0117196817706034

Master, A., Cheryan, S., \& Meltzoff, A. N. (2017). Social group membership increases STEM engagement among preschoolers. Developmental Psychology, 53(2), 201-209. doi: $10.1037 / \operatorname{dev} 0000195$ 
Master, A., Cheryan, S., Moscatelli, A., \& Meltzoff, A. N. (2017). Programming experience promotes higher STEM motivation among first-grade girls. Journal of Experimental Children Psychology, 160, 92-106. doi: 10.1016/j.jecp.2017.03.013

Master, A., Cheryan, S., \& Meltzoff, A. N. (2016). Computing whether she belongs: Stereotypes undermine girls' interest and sense of belonging in computer science. Journal of Educational Psychology, 108(3), 424-437. doi: 10.1037/edu0000061

Midgley, C., Middleton, M. J., Gheen, M. H., \& Kumar, R. (2002). Stage-environment fit revisited: A goal theory approach to examining school transitions. Goals, goal structures, and patterns of adaptive learning, 109-142. Gonzales, L. M., \& Christopher, K. (2014). Status of the geoscience workforce 2014. In American Geosciences Insitute.

Morrow, J. A., \& Ackermann, M. (2012). Intention to persist and retention of first-year students: The importance of motivation and sense of belonging. College Student Journal. 46(3), 483491.

Murphy, M. C., Steele, C. M., \& Gross, J. J. (2007). Signaling Threat: How Situational Cues Affect Women in Math, Science, and Engineering Settings. Psychological Science, 18(10), 879-885. doi: 10.1111/j.1467-9280.2007.01995.x

Museus, S. D., Yi, V., \& Saelua, N. (2017). The impact of culturally engaging campus environments on sense of belonging. Review of Higher Education: Journal of the Association for the Study of Higher Education, 40(2), 187-215. doi: 10.1353/rhe.2017.0001 
National Science Foundation, \& National Center for Education Statistics. (2017). Women, minorities, and persons with disabilities in science and engineering. Special Report NSF 17310.

Packard, B. W., Walsh, L., \& Seidenberg, S. (2004). Will that be one mentor or two? A crosssectional study of women's mentoring during college. Mentoring \& Tutoring: Partnership in Learning, 12(1), 71-85. doi: 10.1080/1361126042000183039

Packard, B. W. L. (2003). Web-based Mentoring: Challenging traditional models to increase women's access. Mentoring \& Tutoring: Partnership in Learning, 11(1), 53-65. doi: $10.1080 / 1361126032000054808$

Rainey, K., Dancy, M., Mickelson, R., Stearns, E., \& Moller, S. (2018). Race and gender differences in how sense of belonging influences decisions to major in STEM. International Journal of STEM Education, 5(10). doi: 10.1186/s40594-018-0115-6

Rattan, A., Savani, K., Komarraju, M., Morrison, M. M., Boggs, C., \& Ambady, N. (2018). Meta-lay theories of scientific potential drive underrepresented students' sense of belonging to science, technology, engineering, and mathematics (STEM). Journal of Perspective Social Psychology, 115(1), 54-75. doi: 10.1037/pspi0000130

Rattan, A., Good, C., \& Dweck, C. S. (2012). “It's ok - Not everyone can be good at math": Instructors with an entity theory comfort (and demotivate) students. Journal of Experimental Social Psychology, 48(3), 731-737. doi: 10.1016/j.jesp.2011.12.012 
Ribera, A. K., Miller, A. L., \& Dumford, A. D. (2017). Sense of Peer Belonging and Institutional Acceptance in the First Year: The Role of High-Impact Practices. Journal of College Student Development, 58(4), 545-563. doi: 10.1353/csd.2017.0042

Rode, O. (2013). Educational and Psychological Aspects of Environmental Awareness and a Sense of Belonging. Discourse and Communication for Sustainable Education, 4(1), 67-79. doi: 10.2478/dcse-2013-0006

Rosenthal, L., Levy, S. R., London, B., Lobel, M., \& Bazile, C. (2013). In Pursuit of the MD: The Impact of Role Models, Identity Compatibility, and Belonging Among Undergraduate Women. Sex Roles, 68(7), 464-473. doi: 10.1007/s11199-012-0257-9

Rosenthal, L., London, B., Levy, S. R., \& Lobel, M. (2011). The Roles of Perceived Identity Compatibility and Social Support for Women in a Single-Sex STEM Program at a Coeducational University. Sex Roles, 65(9),735-736. doi:10.1007/s11199-011-9945-0

Rosenzweig, E. Q., \& Wigfield, A. (2016). STEM Motivation Interventions for Adolescents: A Promising Start, but Further to Go. Educational Psychologist, 51(2), 146-163. doi: $10.1080 / 00461520.2016 .1154792$

Rotgans, J. I., \& Schmidt, H. G. (2017). Interest development: Arousing situational interest affects the growth trajectory of individual interest. Contemporary Educational Psychology, 49, 175-184. doi: 10.1016/j.cedpsych.2017.02.003 
Sánchez, B., Colón, Y., \& Esparza, P. (2005). The Role of Sense of School Belonging and Gender in the Academic Adjustment of Latino Adolescents. Journal of Youth and Adolescence, 34(6), 619-628. doi: 10.1007/s10964-005-8950-4

Shin, J. E. L., Levy, S. R., \& London, B. (2016). Effects of role model exposure on STEM and non-STEM student engagement. Journal of Applied Social Psychology, 46(7), 410-427. doi: $10.1111 /$ jasp. 12371

Shook, N. J., \& Clay, R. (2012). Interracial roommate relationships: A mechanism for promoting sense of belonging at university and academic performance. Journal of Experimental Social Psychology, 48(5), 1168-1172. doi: 10.1016/j.jesp.2012.05.005

Smith, J. L., Lewis, K. L., Hawthorne, L., \& Hodges, S. D. (2013). When Trying Hard Isn’t Natural: Women's Belonging with and Motivation for Male-Dominated STEM Fields as a Function of Effort Expenditure Concerns. Personality and Social Psychology Bulletin, 39(2), 131-143. doi: 10.1177/0146167212468332

Suhlmann, M., Sassenberg, K., Nagengast, B., \& Trautwein, U. (2018). Belonging mediates effects of student-university fit on well-being, motivation, and dropout intention. Social Psychology, 49(1), 16-28. doi: 10.1027/1864-9335/a000325

Syed, M., Azmitia, M., \& Cooper, C. R. (2011). Identity and academic success among underrepresented ethnic minorities: An interdisciplinary review and integration. Journal of Social Issues, 67(3), 442-468. doi: 10.1111/j.1540-4560.2011.01709.x 
Tachine, A. R., Cabrera, N. L., \& Yellow Bird, E. (2017). Home Away from Home: Native American Students' Sense of Belonging During Their First Year in College. Journal of Higher Education, 5, 785-807. doi: 10.1080/00221546.2016.1257322

Thoman, D. B., Arizaga, J. A., Smith, J. L., Story, T. S., \& Soncuya, G. (2015). The Grass Is Greener in Non-Science, Technology, Engineering, and Math Classes. Psychology of Women Quarterly, 38(2), 246-258. doi: 10.1177/0361684313499899

Tracey, T. J. G., \& Sodano, S. M. (2008). Issues of stability and change in interest development. Career Development Quarterly, 57(1), 51-62. doi: 10.1002/j.2161-0045.2008.tb00165.x

Twenge, J. M., Baumeister, R. F., Tice, D. M., \& Stucke, T. S. (2001). If you can't join them, beat them: Effects of social exclusion on aggressive behavior. Journal of Personality and Social Psychology, 81(6), 1058-1069. doi: 10.1037//0022-3514.81.6.1058

Walton, G. M., \& Cohen, G. L. (2011). A brief social-belonging intervention improves academic and health outcomes of minority students. Science (New York, N.Y.), 331(6023), 14471451. doi: 10.1126/science. 1198364

Walton, G. M., \& Cohen, G. L. (2007). A Question of Belonging: Race, Social Fit, and Achievement. Journal of Personality and Social Psychology, 92(1), 82. doi: 10.1037/00223514.92 .1 .82

Wang, X. (2013). Why Students Choose STEM Majors: Motivation, High School Learning, and Postsecondary Context of Support. American Education Research Journal, 50(5), 10811121. doi: $10.3102 / 0002831213488622$ 
Woodcock, A., Hernandez, P. R., \& Schultz, P. W. (2016). Diversifying Science: Intervention Programs Moderate the Effect of Stereotype Threat on Motivation and Career Choice. Social Psychological and Personal Science, 7(2), 184-192. doi:

$10.1177 / 1948550615608401$

Xu, Y. J. (2018). The Experience and Persistence of College Students in STEM Majors. Journal of College Student Retention: Research, Theory \& Practice, 19(4), 413-432. doi: $10.1177 / 1521025116638344$

Yang, Y., Chawla, N. V., \& Uzzi, B. (2019). A network’s gender composition and communication pattern predict women's leadership success. Proceedings of the National Academy of Sciences, 116(6), 2033-2038. doi: 10.1073/pnas.1721438116

Zumbrunn, S., McKim, C., Buhs, E., \& Hawley, L. R. (2014). Support, belonging, motivation, and engagement in the college classroom: A mixed method study. Instructional Science, 42(5), 661-684. doi: jstor.org/stable/43575253 


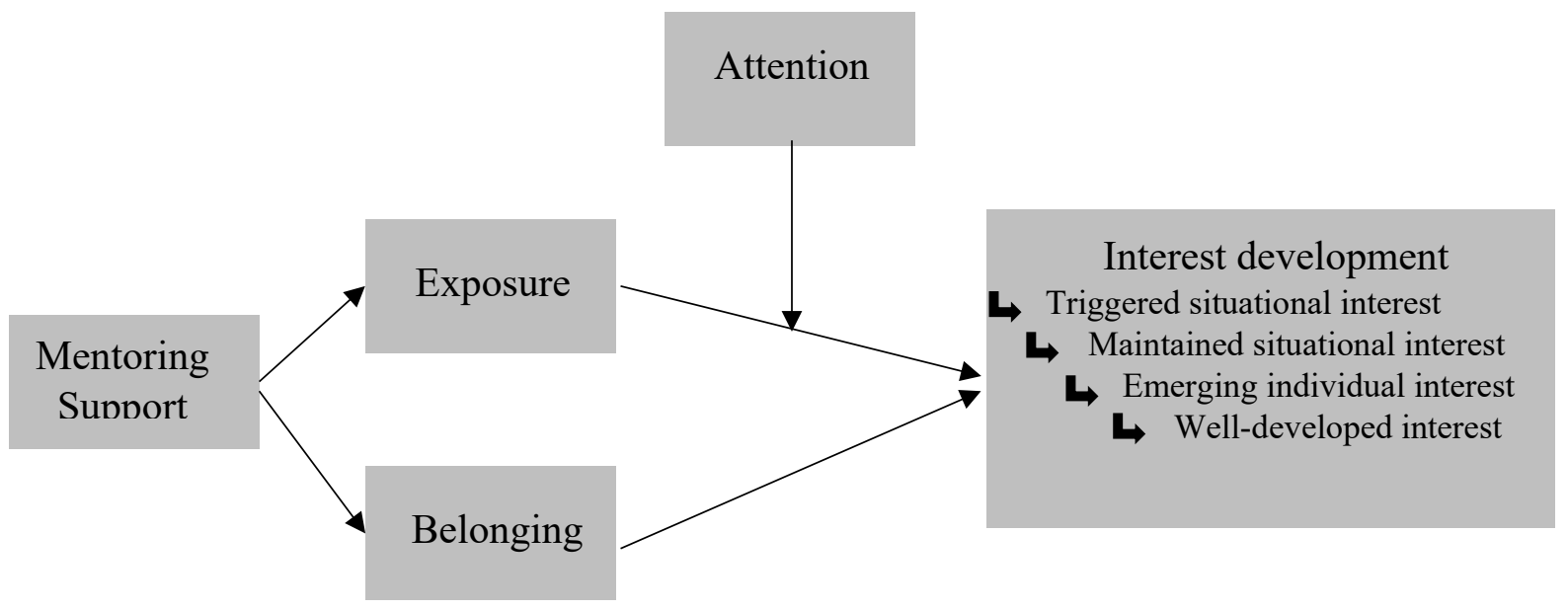

Figure 1. Theory model of mentoring support influences interest development by increasing exposure and belonging. 
Table 1.

Participants' demographic information.

\begin{tabular}{lcc}
\hline Characteristics & $\mathrm{n}$ & $\%$ \\
\hline PROGRESS member & 113 & $40.6 \%$ \\
Cohort I (Fall 2015) & 117 & $42.1 \%$ \\
Race (European) & 189 & $68.0 \%$ \\
STEM major & 376 & $97.4 \%$ \\
Geoscience major & 61 & $21.9 \%$ \\
\hline
\end{tabular}

Note: $(\mathrm{N}=277) . \mathrm{N}=$ total sample size. 
Table 2.

Summary of intercorrelations for all the variables.

\begin{tabular}{|c|c|c|c|c|c|c|c|c|c|c|c|c|c|c|c|c|}
\hline Variable & 1. & 2. & 3. & 4. & 5. & 6. & 7. & 8. & 9. & 10. & 11. & 12. & 13. & 14. & 15. & 16. \\
\hline 1.PROGRESS & - & & & & & & & & & & & & & & & \\
\hline 2. $\mathrm{CC}$ & .05 & - & & & & & & & & & & & & & & \\
\hline 3.MSUD & .03 & -.06 & - & & & & & & & & & & & & & \\
\hline 4.NC A\&T & -.05 & -.06 & -.06 & - & & & & & & & & & & & & \\
\hline 5.NCSU & -.03 & -.10 & -.10 & -.10 & - & & & & & & & & & & & \\
\hline 6.UCB & -.04 & -.11 & -.11 & -.11 & $-.18 * *$ & - & & & & & & & & & & \\
\hline 7.UNCC & .08 & -.09 & -.09 & -.09 & $-.15^{*}$ & $-.16 * *$ & - & & & & & & & & & \\
\hline 8.USC & -.00 & -.08 & -.08 & -.08 & $-.13 *$ & $-.14 * *$ & -.12 & - & & & & & & & & \\
\hline 9.UW & -.01 & -.08 & -.08 & -.08 & $-.13 *$ & $-.15^{*}$ & $-.12 *$ & -.11 & - & & & & & & & \\
\hline 10.Cohort & .04 & -.04 & $.20 * *$ & $.21 * *$ & .00 & $-.14 *$ & -.03 & .11 & -.06 & - & & & & & & \\
\hline 11.Interest W1 & .05 & .07 & .05 & -.04 & -.03 & -.08 & -.03 & $.13^{*}$ & .04 & $.22 * *$ & - & & & & & \\
\hline 12. Faculty & $.15^{*}$ & $.16^{* *}$ & .05 & -.06 & -.01 & .06 & $-.18 * *$ & .07 & .03 & -.02 & $.13^{*}$ & - & & & & \\
\hline 13.F-gender & .10 & .02 & .02 & .03 & .00 & .07 & -.05 & -.03 & .03 & .08 & .07 & $.35 * *$ & - & & & \\
\hline 14.metor div. & $.13 *$ & .06 & -.03 & -.04 & .05 & .05 & $-.13 *$ & .00 & .04 & -.03 & .07 & $.63 * *$ & $.19 * *$ & - & & \\
\hline 15.Belong & -.06 & $-.16^{* *}$ & .01 & .04 & $.21 * *$ & -.02 & -.11 & .07 & -.05 & .03 & $.15^{*}$ & $.14^{*}$ & .10 & $.21 * *$ & - & \\
\hline 16.Interest W6 & $.15^{*}$ & .09 & $.12^{*}$ & -.06 & -.01 & -.06 & -.07 & .06 & .09 & $.12 *$ & $.53 * *$ & $.23 * *$ & $.16^{* *}$ & $.19 * *$ & $.19 * *$ & - \\
\hline $\mathrm{N}$ & 294 & 300 & 300 & 300 & 300 & 300 & 300 & 300 & 300 & 294 & 294 & 279 & 300 & 279 & 300 & 299 \\
\hline Mean & .40 & .06 & .06 & .06 & .12 & .16 & .12 & .10 & .09 & .41 & 3.45 & .49 & .10 & 1.62 & 5.14 & 4.01 \\
\hline SD & .49 & .23 & .23 & .24 & .33 & .37 & .33 & .30 & .29 & .49 & 1.16 & .50 & .30 & 1.22 & 1.15 & 2.13 \\
\hline Skew & .45 & 4.00 & 3.85 & 3.72 & 2.26 & 1.83 & 2.41 & 2.71 & 2.81 & .36 & -2.7 & .05 & 2.74 & .23 & -.71 & .05 \\
\hline Kurtosis & -1.8 & 14.06 & 12.94 & 12.00 & 3.11 & 1.36 & 3.55 & 5.56 & 5.94 & -1.88 & -.87 & .15 & 5.56 & -1.05 & .40 & -1.34 \\
\hline
\end{tabular}

Note. Variable names: 1. PROGRESS membership; 2. Colorado College; 3. Metropolitan State University at Denver; 4. North Carolina A\&T University; 5. North Carolina State University; 6. University of Colorado Boulder; 7. University of North Carolina - Charlotte; 8. University of South Carolina; 9. University of Wyoming; 10. Cohort; 11. Initial interest in geosciences at Wave I; 12. Having a faculty mentor; 13. Gender-matched faculty mentor; 14 . Mentor diversity; 15.

University sense of belonging; 16. Interest in geoscience at Wave VII. ** $\mathrm{p}<.01,{ }^{*} \mathrm{p}<.05$. $(\mathrm{N}=277)$. 
Table 3 .

Summary of Hierarchical Regression with Mentor Diversity Predicting University Sense of Belonging and interest at W6 $(N=277)$.

\begin{tabular}{ccccccc}
\hline & \multicolumn{3}{c}{ Belonging } & \multicolumn{2}{c}{ Interest } & \\
\cline { 3 - 6 } Predictors & $\mathrm{b}$ & $\mathrm{SE}$ & $95 \% \mathrm{CI}$ & $\mathrm{b}$ & $\mathrm{SE}$ & $95 \% \mathrm{CI}$ \\
\hline Intercept & 4.30 & .27 & {$[3.76,4.84]$} & -.77 & .63 & {$[-2.00,0.47]$} \\
CC & -.84 & .31 & {$[-1.44,-.24]$} & .66 & .51 & {$[-.34,1.66]$} \\
MSUD & .01 & .32 & {$[-.62,64]$} & .98 & .53 & {$[-.06,2.01]$} \\
NC A\&T & .30 & .31 & {$[-.32, .91]$} & -.14 & .51 & {$[-1.16, .87]$} \\
NCSU & .60 & .22 & {$[.16,1.04]$} & .12 & .37 & {$[-.61, .86]$} \\
UCB & -.06 & .21 & {$[-.47, .36]$} & .11 & .35 & {$[-.58, .80]$} \\
UNCC & -.21 & .24 & {$[-.67, .26]$} & -.04 & .39 & {$[-.80, .73]$} \\
USC & .22 & .26 & {$[-30, .73]$} & .14 & .43 & {$[-.71, .98]$} \\
UW & -.21 & .25 & {$[-.70, .26]$} & .67 & .41 & {$[-.13,1.47]$} \\
PROGRESS & -.16 & .13 & {$[-.42, .11]$} & .48 & .22 & {$[.05, .92]$} \\
Cohort & -.06 & .14 & {$[-.35, .22]$} & -.01 & .24 & {$[-.48, .46]$} \\
Interest W1 & .15 & .06 & {$[.04, .27]$} & .90 & .09 & {$[.71,1.10]$} \\
Mentor div. & .20 & .06 & {$[.90, .31]$} & .19 & .09 & {$[.01, .37]$} \\
U. Belonging & - & - & - & .20 & .10 & {$[.0004, .40]$} \\
\hline
\end{tabular}

Note. Mentor diversity predict university sense of belonging $\left(\Delta \mathrm{R}^{2}{ }_{1}=.04, \mathrm{p}<.01\right)$; University sense of belonging explained significant amount of variance of interest $\left(\Delta \mathrm{R}^{2}=.01, \mathrm{p}<.05\right){ }^{*} \mathrm{p}<.05, * * \mathrm{p}<.01$. 
Table 4.

Summary of Hierarchical Regression with Gender-matched Faculty Mentor Predicting Sense of Belonging and Interest at W6 $(N=277)$.

\begin{tabular}{|c|c|c|c|c|c|c|}
\hline \multirow[b]{2}{*}{ Predictors } & \multicolumn{3}{|c|}{ Belonging } & \multicolumn{3}{|c|}{ Interest } \\
\hline & b & $\mathrm{SE}$ & $95 \%$ CI & $\mathrm{b}$ & $\mathrm{SE}$ & $95 \% \mathrm{CI}$ \\
\hline Intercept & 4.45 & .27 & {$[3.91,4.98]$} & -.68 & .63 & {$[-1.91,0.55$} \\
\hline $\mathrm{CC}$ & -.88 & .31 & {$[-1.50,-.26]$} & .59 & .51 & {$[-.42,1.60]$} \\
\hline MSUD & .02 & .32 & {$[-.62, .66]$} & .97 & .53 & {$[-.06,2.00]$} \\
\hline NC A\&T & .32 & .32 & {$[-.31, .94]$} & -.11 & .51 & {$[-1.12, .91]$} \\
\hline NCSU & .64 & .23 & {$[.20,1.09]$} & .16 & .37 & {$[-.58, .89]$} \\
\hline UCB & -.05 & .22 & {$[-.48, .37]$} & .08 & .35 & {$[-.61, .77]$} \\
\hline UNCC & -.20 & .24 & {$[-.67, .27]$} & .01 & .39 & {$[-.75, .77]$} \\
\hline USC & .21 & .27 & {$[-.32, .72]$} & .12 & .43 & {$[-.73, .96]$} \\
\hline UW & -.20 & .25 & {$[-.69, .30]$} & .67 & .41 & {$[-.13,1.47]$} \\
\hline PROGRESS & -.15 & .14 & {$[-.42, .12]$} & .46 & .22 & {$[.02, .89]$} \\
\hline Cohort & -.08 & .15 & {$[-.21, .37]$} & -.04 & .24 & {$[-.43, .50]$} \\
\hline Interest W1 & .15 & .06 & {$[.01, .03]$} & .89 & .10 & {$[.70,1.08]$} \\
\hline Faculty mentor & -31 & .15 & {$[.02, .60]$} & .39 & .24 & {$[-.09, .86]$} \\
\hline Gender-matched & .20 & .23 & {$[-.25, .66]$} & .47 & .38 & {$[-.28,1.20]$} \\
\hline Uni. belonging & - & - & - & .20 & .10 & {$[.01, .40]$} \\
\hline
\end{tabular}

Note. Gender-matched faculty mentor predicts university sense of belonging $\left(\Delta R^{2}=.01, p>.05\right)$;

University sense of belonging predicts interest $\left(\Delta \mathrm{R}^{2}=.01, \mathrm{p}<.05\right) . * \mathrm{p}<.05, * * \mathrm{p}<.01$. 


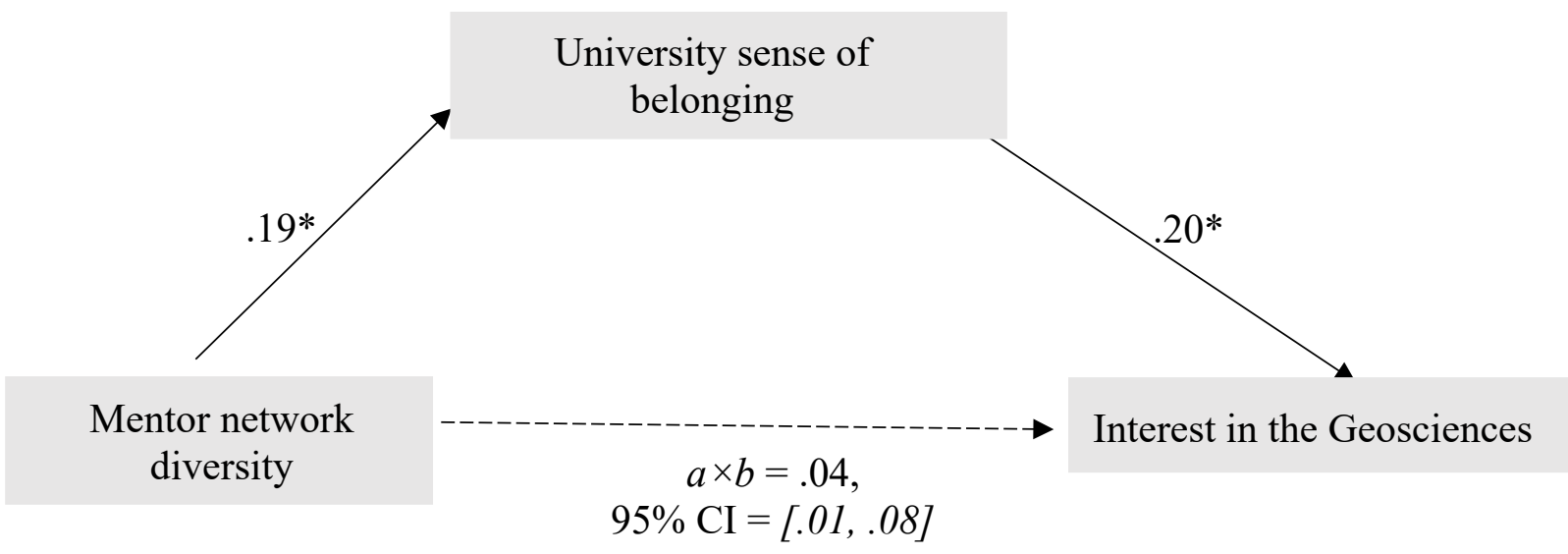

Figure 2. Mediation Analysis. The Effect of Mentor Diversity on Interest in the Geosciences through University Sense of Belonging.

Note. Included the following covariable in mediation analysis: 1. PROGRESS membership; 2. Colorado College; 3. Metropolitan State University at Denver; 4. North Carolina A\&T University; 5. North Carolina State University; 6. University of Colorado Boulder; 7. University of North Carolina - Charlotte; 8. University of South Carolina; 9. University of Wyoming; 10. Cohort; 11. Initial interest in geosciences. 


\section{Appendix A: List of Geoscience Majors}

1. Atmospheric and Oceanic Science

2. Ecosystem Science and Sustainability

3. Ecology

4. Earth Science

5. Environmental Chemistry

6. Environmental Science

7. Environmental Studies

8. Environmental Policy

9. Environmental technology and management

10. Ecosystem Science and Sustainability

11. Geological and Earth Sciences/Geoscience

12. Geology

13. Geophysics

14. Geology/Earth Science, General

15. Geophysics

16. Marine and Coastal Resources

17. Marine Science

18. Meteorology/atmospheric science/Climatology

19. Oceanography

20. Soil and crops science

21. Watershed Science/ Hydrology 


\section{Appendix B: Survey Questions}

\section{University Sense of Belonging Scale ${ }^{[1]}$}

Please answer each question about your university using the following scale.

1. Strongly disagree

2. Disagree

3. Somewhat disagree

4. Neutral

5. Somewhat agree

6. Agree

7. Strongly agree

Q467_1 I am enthusiastic about attending my university.

Q467_2 I am not happy to be at my university (R)

Q467_3 I feel a sense of belonging to my university.

Q467_4 I feel alienated at my university.

Q467_5 I see myself as part of the community at my university.

Q467_6 My university is one of the best schools in the nation.

Q467_7 I identify strongly with my university.

Q467_8 I am a typical student at my university.

sQ467 University belonging (mean Q467_1 to Q467_8)

Note: (R) refelct reverse coded items

${ }^{1}$ Uniersity Sense of Belonging from Shook and Clay (2012), (Adapted) 


\section{Geoscience Interest Scale}

On a scale of 1-7 where 1 equals Strongly Disagree and 5 equals Strongly Agree, how strongly do you agree or disagree with the following statements:
1. Strongly Disagree
2. Disagree
3. Somewhat Disagree
4. Neutral
5. Somewhat Agree
6. Agree
7. Strongly Agree

444a. How interested are you in taking courses in Earth Systems or Environmental Sciences? ${ }^{1}$ 445 b. How interested are you in pursuing an Earth Systems or Environmental Sciences career? ${ }^{2}$

sQ_geoscience_interest $=$ Full form of Geoscience Interests Scale (mean [Q444a - Q445b])

\footnotetext{
${ }^{1}$ Initial Interest (Hulleman et al., 2010), (Adapted)

${ }^{2}$ Interest (Hulleman et al., 2010), (Adapted)
} 


\section{Mentor Network Diversity and Gender-Matched Faculty Mentor Scale}

A mentor is someone who provides guidance, assistance, and encouragement on professional and academic issues. A mentor is more than an academic advisor and is someone you turn to for guidance and assistance beyond selecting classes or meeting academic requirements. The questions in this survey will ask about both formal and informal mentors. Answer each question in regards to your CURRENT mentor unless it specifically asks about a previous mentor.

Q200 Is there a faculty member that you would consider a mentor?

$0-$ No

$1-$ Yes

Q204 What is the gender identity of your faculty mentor?
a. Woman / Female (1)
b. Man / Male
c. Transgender Woman (1)
d. Transgender Man
e. Other

Q209 Students are sometimes mentored by many different people: teachers, program staff, graduate students, peers, coach, community member, etc. Please think about all of the other mentoring you receive including people who were not formally designated as mentors.

Are you currently mentored by any of the following groups of people?
a. Graduate students
b. Peers
c. Other college/university faculty members

$0-$ No

$1-$ Yes

tQ209 = Sum (Q209a - Q209c) 